\title{
Plasma oxalic acid and calcium levels in oxalate poisoning
}

\author{
P. M. ZAREMBSKI AND A. HODGKINSON \\ From the Medical Research Council, Mineral Metabolism Unit, The General Infirmary, \\ Leeds, Yorks.
}

SYNOPSIS Observations are reported on five cases of suicide or attempted suicide by poisoning with oxalic acid or ethylene glycol. Elevated oxalic acid levels were observed in the plasma, stomach contents, and a number of tissues. Raised oxalic acid levels in plasma were associated with reduced total and ultrafilterable calcium levels. It is suggested that the reduction in plasma total calcium level is due mainly to the deposition of calcium oxalate in the soft tissues, but inhibition of the parathyroid glands may be a contributory factor. Microscopic examination of various tissues indicated that oxalic acid is deposited in the tissues in two forms: (1) crystalline calcium oxalate dihydrate in the kidney and (2) a non-crystalline complex of calcium oxalate and lipid in liver and other tissues.

The clinical manifestations and pathological changes associated with oxalic acid poisoning have been described in some detail (Jeghers and Murphy, 1945; Polson and Tattersall, 1959) but there is little or no information regarding the chemical changes which occur in the tissues or body fluids in man. Heubner and Hückel (1935) analysed a number of organs from dogs poisoned with oxalic acid and found the highest levels of oxalic acid (up to 400 mg. $\%$ ) in kidney tissue, but blood oxalic acid levels were not recorded.

The occurrence of tetany in oxalic acid poisoning is well recognized and this has been attributed to the complexing of ionic calcium with oxalic acid. A marked fall in the plasma total calcium level following oxalate poisoning has been noted in man (Koch, 1930) and in animals (Baudouin, Lewin, and Azérad, 1933; Salant, Parkins, and Sheppard, 1933).

In the present paper we report observations on five cases of suicide or attempted suicide by poisoning with oxalic acid or ethylene glycol, which is an indirect source of oxalic acid (Gessner, Parke, and Williams, 1961; Bove, 1966).

\section{PATIENTS}

Observations were made on four women who ingested potassium hydrogen oxalate (salts of lemon). Three of these patients (M.R.F., E.A.L., and M.B.) died as a result of ingesting the salt, the remaining patient (P.E.B.) survived. Observations

Received for publication 20 October 1966. were also made on one man (J.G.) who ingested a lethal dose of ethylene glycol and five 'control' patients who died from causes other than oxalic acid or ethylene glycol poisoning.

\section{METHODS}

Blood samples were obtained from patients M.B. and P.E.B. approximately six hours after ingestion of potassium oxalate and while both patients were still alive. Blood samples from patients M.R.F. and E.A.L., and tissue samples from all four patients who died, were obtained one to three days after death. All samples were analysed immediately or stored in the frozen state $\left(-18^{\circ} \mathrm{C}\right)$ until analysed.

The tissues were homogenized in a Waring blender and then in a Potter-Elvehjem tissue homogenizer. The homogenate was dried on a water bath and fat was removed by extracting with a mixture of benzene and light petroleum ether (Zarembski and Hodgkinson, 1962). Oxalic acid and calcium were extracted from the dry, fat-free residue by heating at $60^{\circ} \mathrm{C}$. with $1 \mathrm{~N} \mathrm{HCl}$ for 30 minutes.

Oxalic acid was determined by a fluorimetric method (Zarembski and Hodgkinson, 1965) and calcium by flame photometry using the Eppendorf flame photometer. Ultrafiltration of plasma was carried out using the apparatus described by Toribara, Terepka, and Dewey (1957).

\section{RESULTS}

PLASMa AND TISSUE OXALIC ACID LeVELS Elevated plasma oxalic acid levels were observed in all the four cases examined, the values being markedly 
raised in two cases (E.A.L. and M.B.). (Table I). The level was only slightly elevated in patient P.E.B. which is consistent with the subsequent recovery of this patient. High oxalic acid levels were also observed in the stomach contents in the three cases examined, in liver in the two cases examined, and in intestine and brain in the one case examined. Specimens of kidney tissue from these patients were not available for analysis.

Plasma oxalic acid levels in five 'control' patients one to three days after death were within the normal range. The levels of oxalic acid in various tissues obtained from 'control' patients were generally less than $0.5 \mathrm{mg}$. per $100 \mathrm{~g}$. of wet tissue the lowest values being observed in the brain and liver (Table I).

PLASMA TOTAL AND ULTRAFILTERABLE CALCIUM The plasma total calcium level was low in patients E.A.L. and M.B. but was within normal limits in patient P.E.B. who recovered. The plasma ultrafilterable calcium was measured in patient M.B. and was found to be very low (Table II).

In contrast, plasma total and ultrafilterable calcium levels in five 'control' patients one to three days after death were higher than normal, ranging from 10.6 to $15.0 \mathrm{mg}$. $\%$ and 6.4 to $12.9 \mathrm{mg}$. $\%$ respectively (Table II).

TABLE II

PLASMA CALCIUM LEVELS

Plasma Calcium (mg. \%)

\begin{tabular}{lcc} 
& \multicolumn{2}{c}{ Plasma Calcium $(\mathbf{m g} . \%)$} \\
\cline { 2 - 3 } Patient & Total & Ultrafilterable \\
\hline E.A.L. & $4 \cdot 1$ & - \\
M.B. & $3 \cdot 7$ & 1.9 \\
P.E.B. & $9 \cdot 8$ & - \\
Controls & $10 \cdot 6-15 \cdot 0$ & $6.4-12.9$ \\
Normal range & $9 \cdot 3-10.7$ & $5 \cdot 7-6.8$
\end{tabular}

DISCUSSION

The present study has confirmed that the ingestion of large amounts of oxalic acid results in a marked elevation of plasma and tissue oxalic acid levels, the $\stackrel{\sim}{\circ}$ levels observed in patients E.A.L. and M.B. being $\omega$ sufficient to complex all or nearly all the ionized calcium in the blood (Kohman, 1934). Plasma ionized calcium levels were not measured in this study but it is apparent from the measurements of total and ultrafilterable calcium (Table II) that the levels of ionized calcium were very low and incompatible with life.

Elevation of the plasma oxalic acid level results in an increase in the calcium $\times$ oxalate ion product. Since calcium oxalate is only sparingly soluble in aqueous solutions at physiological $p \mathrm{H}$ it would be expected to precipitate in the tissues. Such a process might account for the greatly reduced plasma total calcium levels which were observed (Table II). However, microscopic examination has failed to reveal the presence of calcium oxalate crystals in tissues other than the kidney (Heubner and Hückel, 1935; Fazekas, 1958) and no crystals were seen in sections of intestine, liver, or brain from the present patients. Fazekas (1958) suggested on the basis of histochemical studies that there is a disturbance of lipid metabolism in oxalate poisoning. It is well known that calcium forms relatively insoluble soaps with long-chain fatty acids (Yoke, 1958) and the 을 formation of such compounds may account for the $D$ hypocalcaemia observed in acute pancreatitis (Edmondson and Berne, 1944). Preliminary studies $N$ on the tissues from our patients suggest that oxalic acid may be deposited as a non-crystalline complex $N$ of calcium oxalate and lipid in the liver and intestine $\omega$ and further studies are being made to confirm this. श

The observations on patient M.B. indicate that 6 the reduction of plasma total calcium in oxalate $\mathbb{D}$ poisoning occurs before death. This is supported by $\stackrel{?}{+}$ the work of Stewart and Bowen (1951) and Morii, $T$ Fujita, and Okinaka (1963) who observed a prompt suppression of the plasma total calcium level in dogs following the intravenous infusion of sublethal doses of sodium oxalate.

The effect of oxalic acid in lowering the plasma 
ionized calcium level is similar to that of ethylene diamine tetra-acetic acid (E.D.T.A.) but the latter differs from oxalic acid in its effect on plasma total calcium. Thus the intravenous infusion of E.D.T.A. has been found to cause a rapid rise in plasma total calcium (Spencer, Greenberg, Berger, Perrone, and Laszlo, 1956). This effect is probably due to the following sequence of events: reduced plasma ionized calcium level $\rightarrow$ increased parathyroid gland activity $\rightarrow$ increased resorption of bone $\rightarrow$ raised plasma ionized and total calcium levels (Sanderson, Marshall, and Wilson, 1960). This mechanism may be inoperative in the presence of high concentrations of oxalic acid. Oxalic acid is known to inhibit the activity of lactate dehydrogenase (Novoa and Schwert, 1961; Emerson and Wilkinson, 1965) and pyruvate carboxylase (Seubert and Huth, 1965) and further studies may reveal other examples of the inhibitory effects of oxalic acid.

Oxalic acid is only a minor product of ethylene glycol metabolism in mammals (Gessner et al., 1961) but this end-product accounts for an appreciable part of the toxicity of ethylene glycol. Extensive deposits of calcium oxalate have been observed in the renal tubules following ethylene glycol poisoning (Bove, 1966), suggesting that relatively high concentrations of oxalic acid occur in the tissues, despite the low rate of conversion. The observation of a high concentration of oxalic acid in liver tissue (Table I) appears to confirm this conclusion.

It is of interest that the level of total calcium in the 'control' post-mortem plasma samples was higher than normal (Table II). This effect might be due to withdrawal of calcium from the skeleton. Alternatively, it might be due to an efflux of intracellular calcium into the extracellular fluids (Nauss and Davies, 1966) and a further study is being made of this problem.

We wish to thank the following pathologists for the provision of samples and for their cooperation: Dr. C. K. Anderson, University of Leeds; Dr. A. S. Curry, Home Office Forensic Science Laboratory, Nottingham; Dr. Denton Guest, The Royal Infirmary, Huddersfield; Dr. Margaret G. Hamilton, Harrogate General Hospital; Dr. G. Muir, Luton and Dunstable Hospital, and Dr. L. A. C. Summers, York County Hospital. We also wish to thank Dr. B. E. C. Nordin for his helpful comments.

\section{REFERENCES}

Baudouin, A., Lewin, J., and Azérad, E. (1933). C. R. Soc. Biol. (Paris), 112, 367.

Bove, K. E. (1966). Amer. J. clin. Path., 45, 46.

Edmondson, H. A., and Berne, C. J. (1944). Surg. Gynec. Obstet., 79, 240.

Emerson, P. M., and Wilkinson, J. H. (1965). J. clin. Path., 18, 803.

Fazekas, I. G. (1958). Arch. Toxikol., 17, 179.

Gessner, P. K., Parke, D. V., and Williams, R. T. (1961). Biochem. J., 79, 482.

Heubner, W., and Hückel, R. (1935). Arch. exp. Path. Pharmak., 178, 749.

Jeghers, H., and Murphy, R. (1945). New Engl. J. Med., 233, 208.

Koch, F. (1930). Dtsch. Arch. klin. Med., 169, 100.

Kohman, E. F. (1934). J. Amer. diet. Ass., 10, 100.

Morii, H., Fujita, T., and Okinaka, S. (1963). Endocrinology, 72, 173.

Nauss, K. M., and Davies, R. E. (1966). J. biol. Chem., 241, 2918.

Novoa, W. B., and Schwert, G. W. (1961). Ibid., 236, 2150.

Polson, C. J., and Tattersall, R. N. (1959). Clinical Toxicology. English Universities Press, London.

Salant, W., Parkins, W. M., and Sheppard, L. E. (1933). J. Lab. clin. Med., 19, 142.

Sanderson, P. H., Marshall, F., II, and Wilson, R. E. (1960). J. clin. Invest., 39, 662.

Seubert, W., and Huth, W. (1965). Biochem. Z., 343, 176.

Spencer, H., Greenberg, J., Berger, E., Perrone, M., and Laszlo, D. (1956). J. Lab. clin. Med., 47, 29.

Stewart, G. S., and Bowen, H. F. (1951). Endocrinology, 48, 568.

Toribara, T. Y., Terepka, A. R., and Dewey, P. A. (1957). J. clin. Invest., 36, 738.

Yoke, J. T., (1958). J. phys. Chem., 62, 753.

Zarembski, P. M., and Hodgkinson, A. (1962). Analyst (Lond.), 87, 698. 